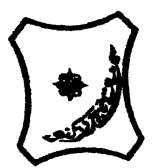

Bayero Journal of Pure and Applied Sciences, 11(1): 183 - 188

Received: January, 2018

Accepted: May, 2018

ISSN $2006-6996$

\title{
ASSESSMENT OF SURFACE WATER PHYSICO-CHEMICAL PARAMETERS OF YARDANTSI RESERVOIR, GUSAU NIGERIA
}

\author{
Jabbi, A.M. ${ }^{* 1}$, Sani, Z.R. ${ }^{2}$, Rabiu, A.T. ${ }^{1}$, Balarabe, M.L.. ${ }^{3}$ and Adamu, A.K. ${ }^{4}$ \\ ${ }^{1}$ Department of Biological Sciences, Faculty of Science, Nigeria Police Academy, Wudil \\ ${ }^{2}$ Department of Biological Sciences, Faculty of Science, Federal University, Gusau, Nigeria \\ ${ }^{3}$ Department of Biology, Faculty of Life Sciences, Ahmadu Bello University, Zaria, Nigeria \\ ${ }^{4}$ Department of Botany, Faculty of Life Sciences, Ahmadu Bello University, Zaria, Nigeria \\ *Correspondence: jabbiam99@gmail.com,+2348030985166
}

\begin{abstract}
The Yardantsi Reservoir, Gusau Nigeria serves multitude of purposes for the Gusau populace. It is the main source of water for domestic purpose, irrigation, and fishing. The reservoir receives both organic and inorganic waste through runoffs and seepage from the catchment areas. The physicochemical parameters of the surface water were investigated monthly from May, 2015 to April, 2017. Samples were collected from five sampling stations and analyzed using standard procedures for examination of water and waste water. The data obtained was subjected to multivariate analysis using Microsoft office excels and SPSS. The results showed the following mean seasonal variation of surface water temperature (26.62 $\pm 0.34-30.12 \pm 0.17 \circ \mathrm{C})$, transparency $(48.82 \pm 1.08$ $22.07 \pm 0.87 \mathrm{~cm})$, mean depth $(2.12 \pm 0.05-2.65 \pm 0.04 \mathrm{~m}), \mathrm{pH}(7.61 \pm 0.15-7.96 \pm 0.13)$, electrical conductivity (186.32 $\pm 3.84-108.05 \pm 5.43 \mu \mathrm{S} / \mathrm{cm})$, total dissolved solids (96.00 1 1.95$63.70 \pm 3.68 \mathrm{mg} / \mathrm{L})$, dissolved oxygen $(7.80 \pm 0.11-6.91 \pm 0.10 \mathrm{mg} / \mathrm{L})$, biochemical oxygen demand $(2.71 \pm 0.09-2.48 \pm 0.05 \mathrm{mg} / \mathrm{L})$, alkalinity $(40.57 \pm 0.69-27.87 \pm 0.51 \mathrm{mg} / \mathrm{L})$, hardness $(59.20 \pm 1.01-$ $32.18 \pm 0.94 \mathrm{mg} / \mathrm{L}), \mathrm{NO}_{3}-\mathrm{N}(2.28 \pm 0.08-4.44 \pm 0.07 \mathrm{mg} / \mathrm{L}), \mathrm{PO}_{4}-\mathrm{P}(123.72 \pm 1.44-173.48 \pm 2.78 \mathrm{mg} / \mathrm{L})$, sulphate (31.62 $\pm 1.45-71.80 \pm 1.82 \mathrm{mg} / \mathrm{L})$ and chloride $(74.08 \pm 1.67-37.64 \pm 0.96 \mathrm{mg} / \mathrm{L})$ for dry and rainy seasons respectively. The results revealed that a highly significant seasonal variation ( $p<0.01)$ was exhibited in all parameters with the exception of pH which shows no significant seasonal variation ( $p>0.05$ ) and biochemical oxygen demand, which shows a significant seasonal variation $(p<0.05)$. The results of this survey showed that the parameters observed indicated that most of them fall within the recommended range set by World Health Organization (WHO) and Nigerian Standard for Drinking Water Quality (NSDWQ).
\end{abstract}

Keywords: Dissolved oxygen, electrical conductivity, pH, reservoir, temperature

\section{INTRODUCTION}

Reservoirs or man-made lakes are impoundments created largely by humans by the damming of river valleys. Humans have created artificial lakes by damming for at least 4000 years. It is only recent that the damming activities have become highly significant for the purpose of flood control, irrigation, and provision of power and water supplies for urban, evergrowing populations (Ismael, 2009). Anthropogenic activities such as agriculture, industrial and domestic discharges have contributed to the deterioration of the environment (Ansari et al., 2014; Van Dover, 2014). Pollutants from these activities are released either directly into the aquatic ecosystem in the form of wastewater discharges, oil spillages, agricultural run-offs (Hassan et al., 2014), or indirectly through deposition from soil or air within the catchment of such water bodies (Bako et al., 2014). In recent years there have been increasing concern about the rate at which inland waters are polluted through human activities, agriculture waste, manure, fertilizers and pesticides, which find their way through run-offs into streams and lakes there by enriching the water bodies, leading to eutrophication (Adakole et al., 2003). The quality of any given water body is governed by its physical, chemical and biological factors, all of which interact with one another and greatly influence its productivity (Ajana et al., 2006). Muhar, et al., (2000) reported that a study of physicochemical characteristics provides great insight into why problems occur; help to discern the trends and asses potential remedies. Therefore monitoring the physico-chemical characteristics of reservoirs is important for both short term and long term trends, which will enable appropriate decisions and action to minimize deleterious effects. This research work is aimed at evaluating some aspect of limnology; physico-chemical parameters with a view of assessing the water quality of Yardantsi Reservoir Gusau.

\section{MATERIALS AND METHODS}

\section{Study Area}

The reservoir is located in Gusau Local Government Area of Zamfara State, (Figure 1), Northwestern Nigeria, located between latitude 12 $10^{\prime} 12.86^{\prime \prime}$ $12^{\circ} 17^{\prime} 02.40^{\prime \prime} \mathrm{N}$ and longitude 6०39'50.83" $6^{\circ} 66^{\prime} 41.20^{\prime \prime} \mathrm{E}$, and occupies an area of $3,364 \mathrm{~km}^{2}$ (1,298.8sqmi). Gusau Local Government had a population of 383,162 people (NPC, 2006). The hottest months in the area are March and April that is just before the onset of the first rains. 


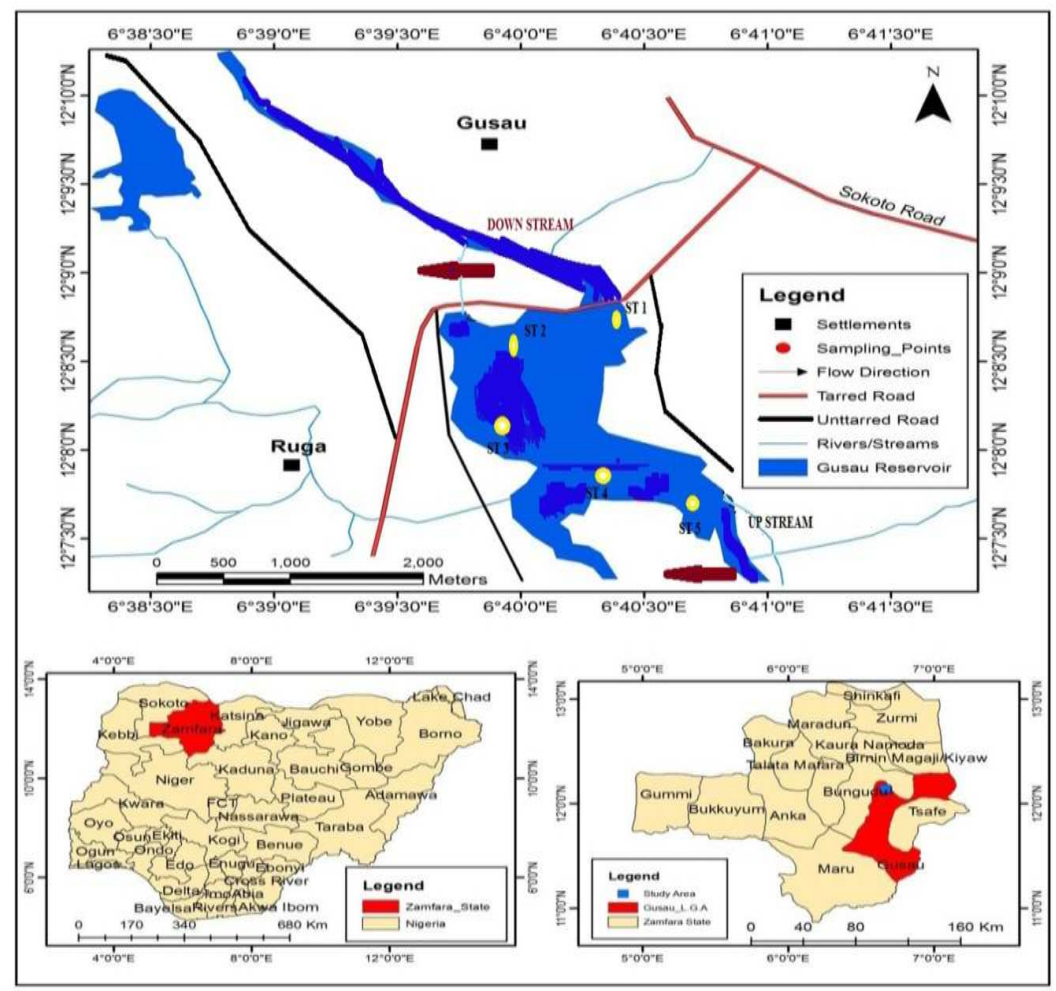

\section{Figure 1: Map of the Study Area Showing Yardantsi Reservoir}

The onset of the rains tends to bring a cooling effect with temperatures dropping below $36^{\circ} \mathrm{C}$. The peak of the rainy season is from July to September except towards the end of October/November when the tropical continental air masses from the Sahara predominate which leads to lower temperatures of around $17^{\circ} \mathrm{C}-20^{\circ} \mathrm{C}$. The mean annual rainfall in the area is $990 \mathrm{~mm}$ (Mamman et al., 2000).

\section{Collection of Surface Water Samples}

The reservoir was divided into five stations, with a distance of $500 \mathrm{~m}$ between the stations. Surface water samples were collected in one litre capacity plastic bottles, from the sampling stations, for the period of twenty four months, to cover four seasons from May 2015 to April 2017. The samples were filtered in the field through a $0.45 \mu \mathrm{m}$ membrane filter and preserved at $4^{\circ} \mathrm{C}$. Each sample collected was taken to the Hydrobiology laboratory of Biology Department Ahmadu Bello University, for determination of physico-chemical parameters. Five water samples were collected for each sampling month, representing one sample per station, for the duration of this research work.

Temperature, $\mathrm{pH}$, electric conductivity and total dissolved solid were determined in situ, using portable HANNA Combo pH/EC/Temp metre model/HI 98129. The metre was calibrated and then the values were recorded as displayed on the meter.

Transparency was determined in situ, using Secchidisc of $30 \mathrm{~cm}$ diameter, by placing the disc vertically with measuring tape attached in the water; the measurement of the distance when the disk disappears from view was recorded as $P_{1}$; The disc was then pull out and the distance when the disk re- appears was measured and recorded as $P_{2}$. The transparency was calculated by taking the average of these distances, using the following formula: Transparency $=\mathrm{P}_{1}+\mathrm{P}_{2} / 2$. Mean depth of each station was determined with string attached with heavy object and a measuring tape. In this method, the depth of each station was measured by dipping the string till it settle down; the measurement was then taken and recorded in metres.

Dissolved oxygen, biochemical oxygen demand, alkalinity, hardness, chloride were determined by titration methods, while phosphate-phosphorus, nitrate-nitrogen, sulphate were determined by colourimetry as described in APHA 2005.

\section{Data Analysis}

IBM SPSS Statistics software version 22 was used for the; Two-way analysis of variance (ANOVA) to analyze the physico-chemical parameters results for significant difference $(p<0.05)$ between the means. Microsoft office excel, 2012 was used for the construction of graphs/charts.

\section{RESULTS AND DISCUSSION}

The results of this research showed a wide range of variation for all the physico-chemical parameters of Yardantsi Reservoir, Gusau. Fourteen (14) physicochemical parameters viz; temperature, transparency, mean depth, $\mathrm{pH}$, total dissolved solid, electrical conductivity, dissolved oxygen, biochemical oxygen demand, alkalinity, hardness, nitrate-nitrogen, phosphate-phosphorus, sulphate and chloride were monitored. The mean seasonal variation of the physico-chemical parameters for the period of these studies are presented in Table 1. 
Variation of these parameters due to pollution (agricultural runoff viz; application of fertilizers, insecticide and herbicide), mixed farming, deforestation along with other climatic factors such as wind and rainfall and their effects on the reservoir were also considered (Tomasz, 2016). Pace et al., (2012) and Lar (2013) reported that the activities in the catchment areas are the most prominent determinants of water quality in an aquatic system.

The mean seasonal surface water temperatures were observed to be $26.62^{\circ} \mathrm{C}$ and $30.12^{\circ} \mathrm{C}$ for dry and rainy season respectively, the higher temperature rainy season may be due to an increasing photoperiod and longer day length (Mohan et al., 2013), this agrees with the findings of Hai et al., (2013) in their studies on Lake Taihu, China. Analysis of variance (Table 2) shows that significant variation existed between seasons and months $(p<0.05)$. The seasonal variation revealed that dry season recorded the lowest; this could be in response to seasonal changes in air temperature resulting from the North-East trade winds (Harmattan) which is typical of the season. This agrees with the findings of Shanur et al., (2015), Magami et al., (2014), Zelalem (2013), Adakole (1995), Balarabe (1989) in their studies on river Dakatia, Bangladesh, Shagari Reservoir, Lake Adale, Ethiopia, River Kubbani and Makwaye lake Zaria respectively.

Table 1: Mean ( $($ SD) Annual and Seasonal Variation of different Surface Water Parameters of Yardantsi Reservoir, Gusau

\begin{tabular}{|c|c|c|c|c|c|c|c|c|}
\hline \multirow[b]{2}{*}{ Metals } & \multicolumn{2}{|c|}{ Years } & \multirow[b]{2}{*}{$\begin{array}{c}\text { P- } \\
\text { valu } \\
\text { e }\end{array}$} & \multicolumn{2}{|c|}{ Seasons } & \multirow[b]{2}{*}{$\begin{array}{c}\text { P- } \\
\text { valu } \\
\text { e }\end{array}$} & \multirow[b]{2}{*}{$\begin{array}{c}\text { NSDW } \\
\mathbf{Q}\end{array}$} & \multirow[b]{2}{*}{$\begin{array}{c}\text { WH } \\
\mathbf{0}\end{array}$} \\
\hline & Year 1 & Year 2 & & Dry Season & $\begin{array}{c}\text { Rainy } \\
\text { Season }\end{array}$ & & & \\
\hline $\begin{array}{l}\text { Temperature } \\
\left({ }^{\circ} \mathrm{C}\right)\end{array}$ & $28.38 \pm 0.35$ & $28.21 \pm 0.35$ & 0.332 & $26.62 \pm 0.34$ & $30.12 \pm 0.17$ & 0.000 & & \\
\hline $\begin{array}{l}\text { Transparenc } \\
\text { y }(\mathrm{cm})\end{array}$ & $35.05 \pm 0.20$ & $36.07 \pm 2.06$ & 0.382 & $48.82 \pm 1.08$ & $22.07 \pm 0.87$ & 0.000 & & \\
\hline Depth (m) & $2.25 \pm 0.04$ & $2.49 \pm 0.06$ & 0.000 & $2.12 \pm 0.05$ & $2.65 \pm 0.04$ & 0.000 & & \\
\hline $\mathrm{PH}$ & $7.97 \pm 1.03$ & $7.61 \pm 0.15$ & 0.082 & $7.61 \pm 0.15$ & $7.96 \pm 0.13$ & 0.091 & $6.5-8.5$ & \\
\hline TDS (mg/L) & $69.14 \pm 3.91$ & $90.54 \pm 2.80$ & 0.000 & $96.00 \pm 1.95$ & $63.70 \pm 3.68$ & 0.000 & 500 & \\
\hline $\mathrm{EC}(\mu \mathrm{s} / \mathrm{cm})$ & $\begin{array}{l}126.46 \pm 6.6 \\
4\end{array}$ & $\begin{array}{l}166.36 \pm 6.3 \\
4\end{array}$ & 0.000 & $\begin{array}{l}186.32 \pm 3.8 \\
4\end{array}$ & $\begin{array}{l}108.05 \pm 5.4 \\
3\end{array}$ & 0.000 & 1000 & \\
\hline DO (mg/L) & $7.29 \pm 0.12$ & $7.45 \pm 0.11$ & 0.150 & $7.80 \pm 0.11$ & $6.91 \pm 0.10$ & 0.000 & & \\
\hline $\mathrm{BOD}(\mathrm{mg} / \mathrm{L})$ & $2.57 \pm 0.08$ & $2.62 \pm 0.07$ & 0.443 & $2.71 \pm 0.09$ & $2.48 \pm 0.05$ & 0.017 & & \\
\hline $\begin{array}{l}\text { Alkalinity } \\
\text { (mg/L) }\end{array}$ & $34.23 \pm 1.00$ & $34.48 \pm 1.07$ & 0.714 & $40.57 \pm 0.69$ & $27.87 \pm 0.51$ & 0.000 & & \\
\hline $\begin{array}{l}\text { Hardness } \\
(\mathrm{mg} / \mathrm{L})\end{array}$ & $45.48 \pm 1.98$ & $46.32 \pm 2.09$ & 0.301 & $59.20 \pm 1.01$ & $32.18 \pm 0.94$ & 0.000 & 150 & \\
\hline $\mathrm{NO}_{3}-\mathrm{N}$ & $3.40 \pm 0.15$ & $3.31 \pm 0.17$ & 0.224 & $2.28 \pm 0.08$ & $4.44 \pm 0.07$ & 0.000 & 50 & 50 \\
\hline $\mathrm{PO}_{4}-\mathrm{P}$ & $\begin{array}{l}148.66 \pm 3.6 \\
9\end{array}$ & $\begin{array}{l}148.72 \pm 4.2 \\
6\end{array}$ & 0.974 & $\begin{array}{l}123.72 \pm 1.4 \\
4\end{array}$ & $\begin{array}{l}173.48 \pm 2.7 \\
8\end{array}$ & 0.000 & & \\
\hline Sulphate & $51.07 \pm 3.06$ & $51.86 \pm 3.20$ & 0.449 & $31.62 \pm 1.45$ & $71.80 \pm 1.82$ & 0.000 & 100 & \\
\hline Chloride & $55.03 \pm 2.71$ & $57.43 \pm 2.79$ & 0.032 & $74.08 \pm 1.67$ & $37.64 \pm 0.96$ & 0.000 & 250 & \\
\hline
\end{tabular}

The relatively circum neutral nature of the water $\mathrm{pH}$ between seasons and the slight fluctuation to alkaline conditions could be regarded as normal, since the mean seasonal values 7.61 and 7.96 for dry and rainy season respectively, obtained in this studies support aquatic life, including fishes and is desirable ranges for fish production as reported by (Mohan et al., 2013 and Adakole, 1995). The values obtained were within the maximum permissible limits (MPL) set by Nigerian standard for drinking water quality(NSDWQ, 2007) and in relation to this the water is considered safe for human consumption and biota. Analysis of variance
(Table 2) shows no significant variation existed between years, seasons, months and stations ( $p>0.05$ ).

The observed variations in $\mathrm{pH}$ among seasons may be due to non-point source inflow of waste water from residential areas, markets, surface run off from agricultural area; geology of the stream bedrock; as well as the hydrobiology of the catchment (Hassan, 2014; Fan and Shibata, 2015; Gara and Staphanian, 2015). 
Bajopas Volume 11 Number 1 June, 2018

Table 2: ANOVA for different Surface Water Parameters of Yardantsi Reservoir, Gusau

\begin{tabular}{|c|c|c|c|c|c|c|c|c|}
\hline Parameters & Year & Season & Month & Station & $\begin{array}{l}\text { Year } \\
\text { by } \\
\text { Month }\end{array}$ & $\begin{array}{l}\text { Year by } \\
\text { Station }\end{array}$ & $\begin{array}{l}\text { Month } \\
\text { by } \\
\text { Station }\end{array}$ & $\begin{array}{l}\text { Year by } \\
\text { Month by } \\
\text { Station }\end{array}$ \\
\hline Temperature & NS & $*$ & $*$ & NS & NS & NS & NS & NS \\
\hline Transparency & . & . & . & . & . & . & . & . \\
\hline Mean Depth & NS & $*$ & NS & NS & NS & NS & NS & NS \\
\hline $\mathrm{PH}$ & NS & NS & NS & NS & NS & NS & NS & NS \\
\hline TDS & $*$ & $* *$ & $*$ & NS & NS & NS & NS & NS \\
\hline EC & $* *$ & $*$ & $*$ & NS & NS & NS & NS & NS \\
\hline DO & NS & $*$ & NS & NS & NS & NS & NS & NS \\
\hline BOD & NS & NS & NS & NS & NS & NS & NS & NS \\
\hline Alkalinity & . & . & . & . & . & . & . & . \\
\hline Hardness & NS & NS & $*$ & NS & NS & NS & NS & NS \\
\hline $\mathrm{NO}_{3}-\mathrm{N}$ & . & . & . & . & $\cdot$ & $\cdot$ & & . \\
\hline $\mathrm{P}-\mathrm{PO}_{4}$ & NS & $*$ & $*$ & NS & NS & NS & NS & NS \\
\hline Sulphate & NS & $* *$ & $*$ & NS & NS & NS & NS & NS \\
\hline Chloride & NS & $*$ & NS & NS & NS & NS & NS & NS \\
\hline
\end{tabular}

$* *=$ Highly significant $(p<0.01) ; *=$ Significant $(p<0.05) ; N S=$ Not significant $(p>0.05) ;$ TDS=Total Dissolved Solid; $\mathrm{EC}=$ Electrical Conductivity; $\mathrm{DO}=$ Dissolved Oxygen; $\mathrm{BOD}=$ Biological Oxygen Demand

Transparency was observed to be significantly higher in dry season than the rainy season with mean seasonal values $48.82 \mathrm{~cm}$ and $22.07 \mathrm{~cm}$ for dry and rainy season respectively, (Table 1 ). The lower transparency observed during rainy season could be attributed by soil erosion, surface runoff and siltation from the catchment as well as the timely discharge of the water to control the reservoir capacity during rainy season thereby mixing the surface water with bottom water and the sediment. Similar findings were reported by Magami et al., (2014), Adakole (1991) and Balarabe (1989) in their studies on Shagari Reservoir, River Kubbani and Makwaye lake Zaria respectively. Analysis of variance (Table 2 ) shows no significant variation existed between years, seasons, months and stations ( $p>0.05$ ).

Electrical conductivity and total dissolved solid were founds to be significantly lower in the rainy season (Table 1); this may be due to dilution of the water as the volume increases and continues discharge of the water to maintain a certain capacity/volume of the reservoir in prevention of flood, as the reservoir is gated. This agrees with the findings of Magami et al., (2014), Devangee et al., (2013), Adakole (1995) and Balarabe (1989) in their studies on Shagari Reservoir, Kankariya, Vastrapur, Malav, and Chandola Lake India, River Kubbani and Makwaye lake Zaria respectively. The values obtained were within the MPL sets by NSDWQ (2007) and in relation to electrical conductivity and total dissolved solid the water is considered safe for human consumption.

Analysis of variance for total dissolved solid (Table 2) shows that significant variation existed between years and months $(p<0.05)$, and a highly significant variation existed between seasons $(p<0.01)$, but no significant variation existed between stations ( $p>0.05)$. While electrical conductivity (Table 2) shows that a highly significant variation existed between years $(p<0.01)$, and a significant variation existed between seasons and months $(p<0.05)$, but no significant variation existed between stations ( $p>0.05)$.

The dissolved oxygen concentrations were observed to have mean seasonal values of $7.80 \mathrm{mg} / \mathrm{L}$ and
$6.91 \mathrm{mg} / \mathrm{L}$ for dry and rainy season respectively, it is significantly higher in dry season, this could be in response to seasonal changes in air temperature resulting from the harmattan and agree with the findings of Devangee et al., (2013) in their studies on Kankariya, Vastrapur, Malav, and Chandola Lake India. Also APHA (2005) explained that dissolved oxygen concentration of above $5 \mathrm{mg} / \mathrm{L}$ is suitable for the support of diverse biota. The highest dissolved oxygen concentrations were recorded in January which coincided with minimum surface water temperature due to seasonal changes in air temperature resulting from the North-East trade winds (Harmattan) which is typical of the season. These findings are in agreement with the Magami et al., (2014), Adakole (1995) and Balarabe (1989).Analysis of variance (Table 2) shows that no significant variation existed between years, months and stations $(p>0.05)$ but a significant variation existed between seasons $(p<0.05)$.

Biological oxygen demand concentration was observed to be higher in dry season (Table 1), which could be due to draw down in water level. The variations between seasons were not significant; this could be due to inflow of organic pollutants along with surface runoff. This agrees with the findings of Tanimu (2015) and Hassan et al., (2014) in their studies on Tudun Wada-Makera Drain and River Kaduna and Hussainiya River, Holy Karbala-Iraq respectively.

Surface water hardness and alkalinity was observed to be higher in dry season (Table 1), this could be attributed to increase in concentration of salts due to draw down in water level and action of wind which enhances the resuspension of sediment calcium and magnesium ions. The rainy season hardness could be attributed to components of artificial fertilizer of alkaline earth metals origin in the form of $\left(\mathrm{NPK}, \mathrm{NH}_{3}\right.$, $\left(\mathrm{NO}_{3}\right)_{2}$ etc) and or pesticide and herbicides from the catchment area runoff. Analysis of variance (Table 2) shows that no significant variation existed between years, seasons and stations $(p>0.05)$ but significant variation existed between months $(p<0.05)$. 
The surface water nitrate-nitrogen, phosphatephosphorusand sulphate recorded the higher concentration in the rainy season (Table 1), which could be attributed to surface runoff from the catchment areas exposed to fertilizer applications as reported by Balarabe (1989) and Tanimu, (2015) in their studies on Makwaye lake and Tudun WadaMakera Drain and River Kaduna respectively. Auro and Cochlan, (2012) reported that phosphorus can be introduced in to the environment in the form of phosphoric acid, phosphate fertilizers, phospholipids in dead tissues while nitrogencan be introduced in to the environment in the form of urea and nitratefertilizers, urine and other forms. The values obtained were within the MPL sets by NSDWQ and in relation to this the water is considered safe for human consumption.

Analysis of variance for phosphate-phosphorus (Table 2) shows that no significant variation existed between years, and stations ( $p>0.05)$, but significant variation existed between seasons and months $(p<0.05)$. The sulphate ANOVA (Table 2) shows that no significant variation existed between years, and stations $(p>0.05)$, but significant variation existed between seasons $(p<0.05)$, and highly significant variation existed between months $(p<0.01)$. The ANOVA for chloride (Table 2 ) shows that no significant variation existed between years, months and stations ( $p>0.05$ ), but significant variation existed between seasons $(p<0.05)$.

Chloride concentration in surface water was found to be higher in dry season than the rainy season (Table 1) for both years. This agrees with the findings of Gadzama et al., (2011). The higher concentration of

\section{REFERENCES}

Adakole, J.A. (1995). The Effects of Pollution on a Stretch of River Kubanni, Zaria, Nigeria (Masters Dissertation, Ahmadu Bello University, Zaria Nigeria). Retrieved from http://hdl.handle.net/123456789/684

Adakole, A. Mbab, C.E. and Dalla, M.A. (2003) A paper presented at $29^{\text {th }}$ International Conference on Millennium Development Goals, Abuja, Nigeria.

Ajana, A.M., Adekoya, B.B., Alunuya, O.A. and Ayansanwo, T.O. (2006). Practical Fish Farming Alliance for Community. Transformation Publishers 22-23.

Ansari, A.A., Trivedi, S., Saggu, S. and Rehman, H. (2014). Mudskipper: A Biological Indicator for Environmental Monitoring and Assessment of Coastal Waters. Journal of Entomology and Zoology Studies, 2(6):2233.

APHA (2005). Standard Methods for the Examination of Water and Wastewater. Published by the American Public Health Association, American Water Works Association, Water Environment Federation, Denver, USA. Dubuque, Iowa. 1287p.

Auro, M.E. and Cochlan, P.C. (2013). Nitrogen Utilization and Toxin Production by Two Diatoms of the Pseudo-Nitzschia Pseudodelicatissima Complex: P. cuspidata chloride in rainy season is important for the metabolic activities in the biota. The values obtained were within the MPL sets by NSDWQ and in relation to this the water is considered safe for human consumption.

\section{CONCLUSION}

The results revealed that a highly significant seasonal variation $(p<0.01)$ was exhibited in all parameters with the exception of $\mathrm{pH}$ which shows no significant seasonal variation $(p>0.05)$ and Biological oxygen demand, which shows a significant seasonal variation $(p<0.05)$. Also it indicated that the parameters observed falls within the recommended range set by World Health Organization (WHO) and Nigerian Standard for Drinking Water Quality (NSDWQ), therefore the water is of good quality for human consumption and to support aquatic life such as fishes.

\section{ACKNOWLEDGEMENT}

This is to acknowledge the technical support of $\mathrm{Mr}$. Sylvanus Orji, Haj. Nafisa, Mal. Magaji, A. of Hydrobiology Laboratory, Dr. Tanimu Yahuza, Dr. I.M.K. Gadzama and Mal. Alhassan Bala of Biology Department, ABU Zaria, and TETFund for financing the research.

\section{CONTRIBUTION OF AUTHORS}

This study provided baseline information on the physico-chemical parameters of the reservoir and it indicated that the water is good for human and animal consumption.

\section{CONFLICT OF INTEREST}

This study is in line with the previous studies conducted using inland aquatic ecosystems within and outside Nigeria.

and P. fryxelliana. Journal of Phycology, 49: 156-169.

Bako, S.P., Ezealor, A.U. and Tanimu, Y. (2014). Heavy Metal Deposition in Soils and Plants Impacted by Anthropogenic Modification of Two Sites in the Sudan Savanna of North Western Nigeria. In: Sariano, M. A. H. (Ed) Environmental Risk Assessment of Soil Contamination. InTech, Croatia. doi: $10.5772 / 57299$.

Balarabe M.L. (1989). Limnology and Zooplankton of Makwaye (Ahmadu Bello University Farm) Lake, Samaru, Zaria - Nigeria (Masters Dissertation, Ahmadu Bello University, Zaria Nigeria). Retrieved from http://hdl.handle.net/123456789/972

Devangee, S., Kinjal, B., Jain, N.K., and Modi, H.A. (2013). Physicochemical Analysis of Water from Various Sources and Their Comparative Studies. IOSR Journal of Environmental Science, Toxicology and Food Technology (IOSR-JESTFT). 5(3): 89-92.

Fan, M. and Shibata, H. (2015). Simulation of Watershed Hydrology and Stream Quality under Land Use and Climate Change Scenerios in Teshio River Watershed, Northern Japan. Ecological indicators, 50:79-89. 
Gadzama, I. M. K. and Mondo N. J. (2011).Assessment of the Influence of Limnological Factors on the Malacofauna of Two Major Man Made Lakes in Zaria, Nigeria. International Journal of Biological and Chemical Sciences 5(5):1898-1906, DOI: http://dx.doi.org/10.4314/ijbcs.v5i5.11

Gara, B.D. and Stapanian, M.A. (2015). A Candidate Vegetative Index of Biological Integrity Based on Species Dominance and Habitat Fidelity. Ecological Indicators, 50:225232.

Hai, X., Guangwei, Z., Boqiang, Q., and Hans, WP. (2013). Growth Response of Microcystis spp. to Iron Enrichment in Different Regions of Lake Taihu, China. Hydrobiologia 700:187202. DOI $10.1007 / \mathrm{s} 10750-012-1229-3$

Hassan, F.M., Salman, J.M. and Abdulameer, (2014). Seasonal Variation of Environmental Properties and Phytoplankton Community in Al-Hussainya River, Holly Karbala- Iraq. Mesopotamia Environmental Journal, 1:5682.

IBM (International Business Machines Corp) SPSS Statistics Software Package, Version 22 (2013).

Ismael K. (2009). Introduction to Limnology. Tanzania Fisheries Research Institute (TAFIRI).

Lar, U.A. (2013). Trace Elements and Health: an Environmental Risk in Nigeria. Earth Science, 2(3): 66-72.

Magami I.M., Adamu T. and Aliero A.A. (2014). Physicochemical Flux and Phytoplankton diversity in Shagari Reservoir, Sokoto, Nigeria. Nigerian Journal of Basic and Applied Science, 21(3\&4): 67-72 DOI: http://dx.doi.org/10.4314/njbas.v22i3.3

Mamman, A.B., Oyebanji, J.O. and Peters, S.W. (2000). Nigeria. A People United a Future Assured. Survey of states, millennium edition, 2: 547-550.

Mohan, V.C., Sharma, K.K. and Sharma, A. (2013). Limnological Profile of ChenaniHydroelectric Reservoir, its Connecting Channel and River Tawi in Udhampur district, India. International Research Journal of Biological Sciences, 2(3): 76-79.

Muhar, S., Schwarz, M., Schmutz, S. and Jungwirth, M. (2000). Identification of Rivers with High and Good Quality: Methodological Approach and Applications in Austria. Hydrobiologia, 422/423(1): 343-358pp.

Nigerian Standard for Drinking Water Quality (NSDWQ) (2007). Approved by: SON Governing Council and Nigerian Industrial Standard NIS 554: 2007. ICS 13.060.20

NPC (2006) National Population Commission Census, Gusau Local Government Gusau. Wikipedia, the free encyclopedia. Retrieved on 10 August, 2017, from http://en.wikipedia.org/wiki/Gusau.

Pace, G., Bella, V.D., Barile, M, Andreani, P., Mancini, A.L. and Belfiore, C. (2012). A Comparison of Macroinvertebrate and Diatom Responses to Anthropogenic Stress in Small Sized Volcanic Siliceous Streams of Central Italy (Mediterranean Ecoregion), Ecological Indicators, 23: 544-554.

Shanur, J.H., Mohosena, Begum Tanu B.T., Haidar, Md. I., Ahmed, T. and Rubel, S.A. (2015). Physico-chemical Characteristics and Accumulation of Heavy Metals in Water and Sediments of the River Dakatia, Bangladesh. International Journal of Fisheries and Aquatic Studies 300-5.

Tanimu, Y. (2015). Algae-Based Indices in Relation to Anthropogenic Impact on Water Quality of Tudun Wada-Makera Drainages and a Segment of River Kaduna (Doctoral Dissertation, Ahmadu Bello University, Zaria Nigeria). Retrieved from http://hdl.handle.net/123456789/8124.

Tomasz, M., Małgorzata, A., Monika, T. and Dorota, N. (2016). Effect of Water Chemistry on Zooplanktonic and Microbial Communities across Freshwater Ecotones in Different Macrophyte-dominated Shallow Lakes. Journal of Limnology, 75(2):262-274. DOI: 10.4081/jlimnol.2015.1338.

Van Dover, C.L. (2014). Impacts of Anthropogenic Disturbances at Deep-Sea Hydrothermal Vent Ecosystems: A review. Marine Environmental Research, 102:59-72.

Zelalem, D.F. (2013). Phytoplankton Biomass and Species Composition in Relation to Some Physical and Chemical Characteristics of Lake Adale, Haramaya Woreda, Oromia Region, Ethiopia. International Journal of Fisheries and Aquaculture.2:87-92. DOI; 10.2478/limre-2013-0010. 